\title{
Penambangan Pasir Komersil di Desa Koto Kandis Tanjung Jabung Timur ditinjau dari Hukum Islam
}

\author{
Tri Kurnia Ningsih, Bahrul Ma'ani dan Masnidar \\ Fakultas Syari'ah IAIN Sulthan Thaha Saifudin Jambi \\ E-mail: masnidarmanaf@gmail.com
}

\begin{abstract}
This study uses the Islamic legal approach with qualitative research methods with techniques for collecting data through observation, interviews, and documentation. The research aims to reveal the commercialization of sand mining in Koto Kandis Village, Dendang District, East Tanjung Jabung Regency, and see how Islamic law views the sand mining activities carried out by the community in Koto Kandis. Based on the research carried out, the results are as follows: First, the process of commercializing sand mining is carried out by the Kandis City farmers using water and land lines. Second, this sand mining has positive impacts such as being able to increase economic income and help meet children's educational needs and deepen river water for smoother waterway trips. The negative impact of sand mining is road damage, air pollution due to dust, increased noise due to sand transport trucks, and a decrease in water quality due to sand mining. Third, in the view of Islam, natural resources in its essence belong to Allah's absolute mandated management, utilization and preservation to humans. In the management, exploration and exploitation of natural resources must pay attention to the preservation of nature and the environment and the sustainability of development. In the process of commercializing sand mining that occurs in Koto Kandis Village can be viewed from various aspects included in Islamic law including: Judging from the Word of Allah SWT in the Qur'an, Judging from the Word of the Prophet Muhammad, Judging from the Fatwa of the Indonesian Ulema Council (MUI), Judging From the Istinbath Method of Islamic Law, Viewed From the Muhammadiyah Tarjih, Judging From the Principles of Fiqh.
\end{abstract}

Keywords: Commercial mining; Sand; Koto Kandis.

\begin{abstract}
Abstrak: Penelitian ini menggunakan pendekatan hukum Islam dengan metode penelitian kualitatif dengan tehnik pengumpulan data melalui observasi, wawancara, dan dokumentasi. Penelitian bertujuan mengungkap komersialisasi penambangan pasir di Desa Koto Kandis Kecamatan Dendang Kabupaten Tanjung Jabung Timur, dan melihat bagaimana pandangan hukum Islam mengenai kegiatan penambangan pasir yang dilakukan oleh masyarakat di Koto Kandis tersebut. Berdasarkan penelitian, kesimpulan penelitian sebagai berikut: pertama, proses komersialisasi penambangan pasir ini dilakukan para petani Kota Kandis menggunakan jalur air dan darat. Kedua, penambangan pasir ini berdampak positif yang diantaranya dapat meningkatkan pendapatan ekonomi dan membantu memenuhi kebutuhan pendidikan anak serta memperdalam air sungai untuk perjalanan jalur air yang lebih lancar. Dampak negatif dari penambangan pasir ini jalan hancur, polusi udara akibat debu, peningkatan kebisingan akibat lalulalang truk pengangkut pasir, dan penurunan kualitas air akibat penambangan pasir. Ketiga, dalam pandangan Islam, sumber daya alam pada hakikatnya milik absolut Allah yang diamanatkan pengelolaan, pemanfaatannya dan pelestariannya kepada manusia. Dalam pengelolaan, eksplorasi dan eksploitasi sumber daya alam harus memperhatikan kelestarian alam dan lingkungan serta keberlanjutan pembangunan. Dalam proses komersialisasi penambangan pasir yang terjadi di Desa Koto Kandis dapat ditinjau dari basis hukum Islam diantaranya ditinjau dari firman Allah SWT Dalam Al-Qur'an; Ditinjau dari Sabda Rasulullah SAW; Ditinjau dari Fatwa Majelis Ulama Indonesia (MUI); Ditinjau dari Metode Istinbath Hukum Islam; Ditinjau dari Tarjih Muhammadiyah, dan ditinjau dari Kaidah-Kaidah Fiqih. Kata-kata kunci: Penambangan Komersil; Pasir; Hukum Islam; Koto Kandis.
\end{abstract}




\section{Pendahuluan}

Kerusakan lingkungan diakibatkan oleh berbagai faktor, antara lain oleh pencemaran. Pencemaran ada yang diakibatkan oleh alam, dan ada pula yang diakibatkan oleh perbuatan manusia. Pencemaran akibat manusia adalah akibat dari aktivitas yang dilakukannya. Lingkungan dapat dikatakan tercemar jika dimasuki atau kemasukan bahan pencemar yang dapat mengakibatkan gangguan pada mahluk hidup yang ada didalamnya. Akibat selanjutnya lingkungan semakin rusak dan mengalami pencemaran. Pencemaran lingkungan terbagi atas tiga jenis, berdasarkan tempat terjadinya, yaitu: pencemaran udara, pencemaran air dan pencemaran tanah. Di Indonesia, kerusakan lingkungan akibat pencemaran udara, air dan tanah sudah sangat kritis.

Industri pertambangan merupakan salah satu industri yang diandalkan pemerintah Indonesia untuk mendatangkan devisa. Selain mendatangkan devisa industri pertambangan juga menyedot lapangan kerja dan bagi Kabupaten dan Kota merupakan sumber Pendapatan Asli Daerah (PAD).

Dalam proses yang terjadi di lapangan terkadang tidak sesuai dengan yang diharapkan. Sementara itu di dalam Al-Qur"an Allah SWT menjelaskan betapa penting menjaga dan melestarikan lingkungan salah satunya yaitu Al-Qur"an surat Al Baqarah Ayat 164 yang artinya : "Sesungguhnya dalam penciptaan langit dan bumi, silih bergantinya malam dan siang, bahtera yang berlayar di laut membawa apa yang berguna bagi manusia, dan apa yang Allah turunkan dari langit berupa air, lalu dengan air itu dia hidupkan bumi sesudah mati (kering)-nya dan dia sebarkan di bumi itu segala jenis hewan, dan pengisaran angin dan awan yang dikendalikan antara langit dan bumi; sungguh (terdapat) tanda-tanda (keesaan dan kebesaran Allah) bagi kaum yang memikirkan". ${ }^{1}$

Pasal $28 \mathrm{H}$ ayat (1) dan Pasal 33 ayat (4) UUD 1945 merupakan ketentuan kunci tentang diaturnya norma mengenai lingkungan di dalam konstitusi. Secara berturut-turut kedua Pasal tersebut berbunyi sebagai berikut:

Pasal $28 \mathrm{H}$ ayat (1) : "Setiap orang berhak hidup sejahtera lahir dan batin, bertempat tinggal, dan mendapatkan lingkungan hidup yang baik dan sehat serta berhak memperoleh pelayanan kesehatan".

Pasal 33 ayat (4) : "Perekonomian nasional diselenggarakan berdasar atas demokrasi ekonomi dengan prinsip kebersamaan, efisiensi berkeadilan, berkelanjutan, berwawasan lingkungan, kemandirian, serta dengan menjaga keseimbangan kemajuan dan kesatuan ekonomi nasional".2

Berdasarkan kedua Pasal tersebut di atas maka sudah jelas bahwa UUD 1945 juga telah mengakomodasi perlindungan konstitusi baik terhadap warga negaranya untuk memperoleh lingkungan hidup yang memadai maupun jaminan terjaganya tatanan lingkungan hidup yang lestari atas dampak negatif dari aktivitas perekonomian nasional. Kondisi seperti ini terjadi di Desa Koto Kandis Kec. Dendang Kab. Tanjung Jabung Timur. Desa Koto Kandis merupakan desa yang paling dekat dengan aliran sungai batang hari, untuk saat ini dieksploitasi sumber daya alamnya untuk diambil pasirnya. Pasir yang dihasilkan oleh aliran air batang

${ }^{1}$ Al-Quran, surat Al-Baqarah (2): 164

2 Undang-Undang Dasar RI Tahun 1945, Tentang Lingkungan Didalam Konstitusi , Pasal 28 dan 33 Ayat 1 dan 4 . 
hari tersebut merupakan bahan tambang yang menggiurkan banyak orang. Penduduk yang sebagian besar bermata pencaharian sebagai petani dan nelayan tersebut seringkali menambang pasir sebagai penghasilan tambahan.

Berdasarkan observasi di lapangan diperoleh situasi yang sangat tidak layak untuk dilihat. Karena banyak sekali para penambang di Desa Koto Kandis tersebut yang tidak memenuhi izin untuk menambang pasir. Selain itu, daerah penambangan pasir tersebut juga dekat dengan lingkungan masyarakat yang hidup di sepanjang sungai batanghari. Hampir setiap hari mereka mencari pasir ada yang menggunakan peralatan modern ada pula yang secara tradisional atau alat seadanya. Pasir yang sudah disaring mengunakan alat penyaringan langsung dimasukkan kedalam pompong untuk diangkut ke pembeli atau pun sekedar diangkut ke tepi sungai ditumpuk sehingga jika ada yang beli atau memesan tinggal diangkut menggunakan mobil truk.

Sungai batanghari bagi sebagain besar masyarakat Desa Koto Kandis adalah suatu kebutuhan yang tak dapat dipisahkan. Dimana mereka mandi, memasak, mencuci dan lain-lain menggunakan air sungai batang hari. Namun dengan adanya penambangan pasir tersebut berpengaruh sangat besar terhadap kebersihan air di sekitar pemukiman warga di Desa Koto Kandis. Penelitian ini menggunakan metode kualitatif deskriptif, dengan melakukan observasi dan wawancara dengan Kepala Desa Koto Kandis, Tokoh agama, tokoh masyarakat, warga desa Koto Kandis yang berjumlah empat orang.

\section{Komersialisasi dan Pertambangan}

Dalam Kamus Besar Bahasa Indonesia (KBBI), komersialisasi diartikan sebagai perbuatan menjadikan sesuatu sebagai barang dagangan. ${ }^{3}$ Komersialisasi Pertambangan dapat bermakna memperdagangkan hasil pertambangan ,karena menurut kamus, kata komersial atau commercialize berarti memperdagangkan atau perdagangan. Sedangakan pengertian Perdagangan itu sendiri adalah seluruh kegiatan usaha dagang yang dilakukan orang-orang dan badan-badan, yaitu dalam pembelian dan penjualan atau pertukaran barang dan jasa, yang bertujuan untuk memperoleh keuntungan. ${ }^{4}$ Tujuan-tujuan kegiatan Komersialisasi (perdagangan) antara lain: 1) Memenuhi kebutuhan manusia, 2) Memperoleh penghasilan, 3) Mengusahakan pemerataan hasil, 4) Meningkatkan kemakmuran masyarakat, 5) Mendorong kegiatan ekonomi lainnya, 6) Mendorong kemajuan dibidang-bidang tertentu. ${ }^{5}$ Hal-hal yang mendorong terjadinya Komersialisasi (perdagangan) yaitu: 1) Kebutuhan manusia yang tidak terbatas dan beraneka ragam jenisnya, 2) Adanya perbedaan kecakapan antara manusia yang satu dengan yang lainnya, 3) Letak geografis dimana manusia itu hidup, 4) Latar belakang dan kemajuan pendidikan, kebudayaan, berhubungan, dan bidang teknik, 5) Pertambahan jumlah penduduk. ${ }^{6}$

Komersialisasi (perdagangan) adalah merupakan penghubung keduanya, maka pada dasarnya tugas-tugas Komersialisasi (perdagangan), antara lain sebagai berikut: 1) Mengumpulkan atau membeli barang dagangan, 2) Memilih

\footnotetext{
3 Dessy Anwar, Kamus Besar Bahasa Indonesia (Surabaya: Amelia Surabaya, 2005), hlm.179

4. Hamzah Ya"qub,Etos Kerja Islami,(Jakarta: CV. Pedoman Ilmu Jaya, 1992), hlm. 26

5 . Hamzah Ya"qub,Etos Kerja Islami, hlm. 27

${ }^{6}$ Hamzah Ya"qub,Etos Kerja Islami, hlm. 28
} 
atau menyortir dan mengelompokkan barang-barang dalam kualitas tertentu, 3) Menyimpan barang, 4) Memindahkan barang ketempat yang tidak ada atau kekurangan barang tersebut, 5) Membagikan atau mendistribusikan barang dari produsen kepada konsumen dengan jalan penjualan. ${ }^{7}$ Untuk mencapai kelancaran dalam Komersialisasi (perdagangan), ada beberapa alat perlengkapan yang biasa digunakan, antara lain: 1) Alat tukar menukar, seperti: uang kertas dan logam, 2) Alat-alat pengukur seperti: pengukur berat, pengukur isi, panjang pengukur luas, dan lain-lain; 3)Dikumen-dokumen dagang seperti: surat kontrak, bukti order, bukti penawaran, tanda terima, dan lain-lain, 4) Alat-alat komunikasi seperti: telepon, dan 5) Alat transportasi seperti: mobil, motor, kapal atau pompong. ${ }^{8}$

Dalam proses pertukaraan barang dengan persetujuan antara kedua belah pihak, seringkali ada konflik. Untuk menghindari ini, Nabi telah meletakkan dasar, bagaimana transaksi seharusnya terjadi. Ibnu umar meriwayatkan,"kedua kelompok didalam transaksi perdagangan berhak membatalkan hanya sejauh mereka belum berpisah, kecuali transaksi itu menyulitkan kelompok itu untuk membatalkannya. ${ }^{9}$

Pertambangan merupakan suatu aktivitas penggalian, pembongkaran serta pengangkutan suatu endapan mineral yang terkandung dalam suatu area berdasarkan beberapa tahapan kegiatan secara efektif dan ekonomis dengan menggunakan peralatan mekanis serta beberapa peralatan sesuai dengan perkembangan teknologi saat ini. ${ }^{10}$

Proses penambangan pasir yang dilakukan di Desa Koto Kandis Kecamatan Dendang Kabupaten Tantung Jabung Timur yaitu dilakukan dengan cara tradisional. Penambangan pasir yang dilakukan hanya dengan menggunakan alatalat yang sederhana seperti: pengeruk pasir, dan karung sebagai tempat penyimpanan pasir. Kendaraan yang dipakai untuk mencari pasir oleh masyarakat di Desa Koto Kandis adalah pompong yang langsung dapat di gunakan mencari pasir di sungai batang hari. Beberapa tahapan yang dilakukan dalam penambangan pasir diantaranya adalah: Tahap Persiapan yang didahului dengan kegiatan pengangkutan berbagai jenis peralatan tambang. Dalam hal pengangkutan peralatan tambang masyarakata di Desa Koto Kandis menggunakan kendaraan air yaitu pompong. Hal ini perlu lebih mempermudah untuk mengangkut pasir yang telah dikumpulkan kepermukaan air. Pada tahap ini dilakukan pengamatan, dimana saja biasanya pasir akan terkumpul banyak, maka setelah diketahui lokasinya, maka masyarakat akan langsung melakukan penggalian pasir; Kedua, Tahap Eksploitasi atau Penggalian. Pada kegiatan yang dilakukan pada tahap ini utamanya berupa penambangan atau penggalian pasir, bahan tambang yang terdapat di dasar sungai. Pengambilan pasir biasanya dilakukan dengan alat pengeruk yang sederhana, namun, sekali-kali apabila kedaan sungai kering biasanya alat berat seperti beko bisa langsung masuk ke lokasi penambangan. Ketiga, Pada tahap ini yang perlu diperhatikan adalah ketika alat-alat berat mulai masuk ke lokasi penambangan untuk mengangkut pasir. Pengangkutan pasir ini

${ }^{7}$ Hamzah Ya"qub,Etos Kerja Islami, hlm. 28-29

8 Ibid.,hlm. 30-31

${ }_{9}^{9}$ M. Luthfi Hamidi, Jejak-jejak Ekonomi Syariah, ( Jakarta: Senayan Abadi Publishing, 2003), hlm. 326; Totok Suhartono,"PertambanganBahangaliangolonganC" http://data.menkokesra.go.id/content/program- penyehatan-lingkungan akses 22 Januari 2014 
biasanya dilakukan dengan menggunakan truk, untuk mencapai kawasan penambangan secara mudah, truk tersebut melalui jalan-jalan yang ada di Desa Koto Kandis. Akibatnya karena sering di lalui oleh kendaraan bertonase berat jalan menjadi rusak dan berdebu.

\section{Komersialisasi Penambangan Pasir di Desa Koto Kandis}

Desa Koto Kandis merupakan daerah pertanian pasang surut disepanjang dua aliran sungai tersebut dan perkebunan dibahagian dalam, kurang lebih 100 sampai $500 \mathrm{~m}$ dari tepi sungai. Adapun wilayah Koto Kandis terbagi dalam Sembilan Dusun dengan 40 Rukun Tetangga (RT) yang luas wilayahnya 99,27 km. Potensi sumber daya alam berupa pertanian, perkebunan, peternakan dan perikanan adalah meruapakan potensi sumber daya unggulan Desa Koto Kandis yang mendominasi aktifitas masyarakat yakni hampir $95 \%$ masyarakat Koto Kandis adalah petani, peternak, nelayan dan sebagiannya adalah pedagang dan pegawai Negeri Sipil.

Pada tahun 2013, kondisi ekonomi Desa Koto Kandis secara perlahan mulai ada peningkatan seiring dengan perkebunan sawit masyarakat mulai berproduksi disamping sistem pertanian dikelola secara insentif atau ekstensif dengan pola TAM dan Optimalisasi, ini ditandai dari data penerima manfaat raskin semakin berkurang dari 250 KK tahun 2011, menjadi 178 pada tahun 2012 dan 167 untuk tahun 2013.11 Masyarakat Desa Koto Kandis menambang pasir di Sungai Batanghari dengan sistem 1 bulan sekali menjelang buah sawit besar dan masak setelah buah sawit membesar dan mulai matang maka petani berhenti mencari pasir dan mulai memanen sawitnya.

Hasil dari memanen sawit terkadang tidak cukup untuk memenuhi kebutuhan pokok masyarakat Desa Koto Kandis karena untuk hasil dari buah sawit ini sangat bergantung dengan harga jual. Jika harga jual tinggi maka masyarakat akan mendapatkan keuntungan yang banyak, namun jika harga jual tandan buah murah maka masyarakat Desa Koto Kandis berusaha mencari alternatif lain agar bisa menambah peghasilan, salah satu caranya yaitu dengan cara menambang pasir di sepanjang aliran sungai batanghari.

Proses Komersialisasi hasil tambang pasir ini dilakukan para petani dengan menggunakan pompong melalui perjalanan air atau menggunakan truk-truk besar. Tergantung dengan pesanan yang diterima oleh petani atau masyarakat penambang. Biasanya pesananan tambang pasir ini ada yang berasal dari daerah setempat digunakan untuk membangun rumah, jembatan dan jalan-jalan di daerah setempat. Selain pemesanan lokal ada juga pemesan yang datang dari luar seperti daerah Sabak Barat, Tungkal dan daerah Nipah Panjang. Sebagaimana pengakuan dari Bapak imam "hasil dari penambangan pasir ini biasanya dijual kepembeli yang ada disekitar Desa Koto Kandis ini dan ada pula yang dari luar Desa". ${ }^{2}$ Jika pembeli ingin membeli pasir ada yang datang secara langsung dan sekaligus bernegoisasi harga yang sesuai dengan pembeli selain pembeli datang langsung ada juga yang memesan atau membeli melalui media telekomunikasi yaitu telepon genggam. Pembeli menelepon penambang Pasir. Pengakuan dari Bapak Ambo" ala"

11 Dokumentasi, Kantor Desa Koto Kandis Kec. Dendang, Ekonomi desa Koto Kandis, tgl 17 Maret 2014.

12 Wawancara dengan Imam, penambang pasir Desa Koto Kandis, tgl 17 Maret 2014. 
"pembeli itu ada yang datang langsung dan runding dengan saya masalah harga namun ada juga yang memesan lewat HP karena sudah langganan kami jadi sudah punya nomor HP saya". 13

Hasil pasir yang dihasilkan dari proses tambang di Desa Koto Kandis ini cukup bagus kualitasnya selain bersih juga tidak terlalu halus, maka tidak heran jika banyak sekali pembeli yang memesan pasir kepenambang yang ada di Desa Koto Kandis, proses penambangan yang manual dan menjaga kualitas maka itulah yang menjadi prioritas utama masyarakat Desa Koto Kandis ini, setiap hasil tambang yang sudah di kumpulkan ditampung di penampungan yang sudah disediakan. Pengakuan dari Bapak Khudori "Sengaja kami membuat tempat penambangan pasir di dekat sungai batanghari yang kira-kira luasnya setengah hektar khusus untuk menumpukan pasir yang sudah diambil dari Sungai Batanghari".14

Selain pasir yang ditumpuk di tempat penumpukan pasir ada juga batu-batu koral untuk proses pemasaran masing-masing memiliki harga yang berbeda. Pasir yang sudah ditumpuk terkadang tidak langsung dapat terjual, jika tidak langsung terjual maka pasir tersebut akan menjadi debu dan membuat masyarakat kurang nyaman, seperti pengakuan Ibu Endah warga sekitar tempat penumpukan pasir "kadang kalau musim panas harus banyak angin pasir-pasir yang halus itu terbang dibawa angin akibatnya masuk-masuk rumah pentilasi jadi kotorlah rumah kami ini". ${ }^{15}$ Jika musim hujan tiba pasir-pasir tersebut yang sudah ditumpuk akan terbawa oleh air hujan dan semakin lama akan semakin berkurang banyak.

Pengakuan dari Bapak Ambo" Tang " kalau hujan datang dan pasir belum habis pasir itu dibawa air. Selain rugi uang, saya juga rugi waktu lama. Saya ngumpulin pasir datang hujan banyak berkurang pasir tersebut". ${ }^{16}$

Untuk proses pengambilan pasir ini dilakukan dengan cara manual yaitu hanya menggunakan serok yang terbuat dari potongan jerigen atau membuat dari seng dan diberi pegangan dari bambu yang panjang. Sehingga dengan mudah mengambil pasir yang ada didasar Sungai Batanghari untuk proses penambangan ini tidak dilakukan oleh satu atau dua orang saja. dalam sakali jalan biasanya dilakukan oleh serombongan penambang yang lebih dari 15 orang. Dengan cara beramai-ramai ini diharapkan bisa saling membantu antara penambang satu dengan yang lainnya, dalam satu pompong terdiri dari 3 orang dimana masingmasing dari mereka ikut mencari pasir agar pompong cepat terisi penuh. Jika sudah penuh maka mereka tidak langsung pulang mereka menunggu teman-teman mereka jika sudah penuh semua barulah mereka pulang bersama.

Dari sekian banyak penambang pasir tersebut tidak seluruhnya merupakan warga Desa Koto Kandis ada yang berasal dari Desa lain, jika penambang dari Desa lain. Pasir yang mereka bawa langsung dijual atau langsung mereka antar ketempat pemesanan, jadi tidak ada yang ditumpuk ditempat penampungan. Lokasi penambangan pasir ini dilakukan ditepian Sungai Batanghari warga sekitar menyebutnya teluk yaitu bagian Sungai Batanghari yang berbelok, karena aliran sungai yang terus menerus sehingga menumpuklah pasir ini dibagian teluk-teluk

13 Wawancara dengan Ambo"ala", Penambang pasir Desa Koto Kandis tgl 17 Maret 2014.

14.Wawancara dengan Khudori, penambang pasir Desa Koto Kandis, tgl 17 Maret 2014.

15 . Wawancara dengan Endah, Warga Sekitar Tempat Penumpukan Pasir Desa Koto Kandis, tgl 17 Maret 2014.

16 Wawancara dengan Ambo" Tang, penambang pasir Desa Koto Kandis tgl 17 Maret 2014. 
di Sungai Batanghari, menyebabkan Sungai Batanghari menjadi dangkal banyak sekali kapal-kapal besar yang kandas diteluk ini karena dangkal oleh karena itu dengan adanya penambangan ini sedikit demi sedikit mengurangi kedangkalan tersebut.

Pengakuan dari Bapak Hasanudin, "sebelum ada penambangan pasir di sungai batanghari ini dulu jika air surut akan terlihat pantai disepanjang teluk itu namun sampai sekarang juga masih ada tetapi tidak setinggi dulu, sedikit demi sedikit mulai berkurang". ${ }^{17}$ Menurut kepala desa, Desa Koto Kandis sudah hampir lima tahun proses penambangan namun tumpukan pasir diteluk Sungai Batanghari tersebut masih sangat banyak dan bisa dikatakan belum berkurang. Jika air sedang pasang besar pantai tersebut akan tenggelam seluruhnya tertutup oleh air. Dan jika air surut kembali akan tumpukan pasir di pantai tersebut akan kembali seperti semula begitu seterusnya. Selain itu sesuai dengan peraturan pemerintah tentang pengendalian penambangan pasir laut presiden republik indonesia: "bahwa dalam rangka optimalisasi pemanfaatan hasil penambangan pasir laut, perlu dilakukan pengendalian atas kegiatan penambangan, pengusahaan, dan ekspor pasir laut untuk kepentingan pembangunan nasional, dengan memperhatikan kelestarian ekosistem di wilayah penambangan pasir laut; bahwa sehubungan dengan hal tersebut, dipandang perlu mengeluarkan Instruksi Presiden tentang Pengendalian Penambangan Pasir Laut".

Dari peraturan pemerintah tersebut jelas mengatakan bahwa kegiatan komersialisasi harus dilakukan secara optimal agar dapat digunakan untuk kepentingan pembangunan nasional. Jika tidak maka kegiatan komersialisasi hasil tambang yang dilakukan oleh masyarakat Desa Koto Kandis dapat melanggar peraturan tersebut dan terancam hukuman penjara. Dalam UU Nomor 4 Tahun 2009 Tentang Hukum Pertambangan dan Batubara, yang salah satu pasalnya menegaskan bahwa setiap orang yang melakukan usaha penambangan tanpa Izin Usaha Pertambangan dipidana penjara paling lama 10 tahun dan denda paling banyak 10 Milyar, dan juga sesuai KUHPidana para pelaku penambangan pasir secara liar dikenakan pasal pencurian dan pengerusakan.

\section{Dampak dari Penambangan Pasir terhadap Masyarakat}

Penambangan pasir yang dilakukan oleh warga Desa Koto Kandis hanya sebagai sampingan saja bukan merupakan penghasilan utama, karena disamping mencari pasir mereka juga berkebun dan bertani jika ada pesanan barulah mereka mencari pasir. Untuk perkebunan sendiri ada yang bercocok tanam palawija berupa cabai, sayuran, jagung dan ubi kayu, ada juga yang berkebun kelapa sawit bidang pertanian masyarakat Desa Koto Kandis mayoritas bertani padi. Hasil, dari palawija tidak bisa didapatkan setiap saat hanya bisa dua atau tiga hari saja dalam setahun, dalam setahun tidak ada tanaman lain yang bisa ditanam karena faktor tanah yang kurang baik di Desa Koto Kandis. Kebun kelapa sawit yang warga miliki juga rata-rata belum menghasilkan baru buah pasir jika dijual harganyapun murah. Untuk kebun sawit ini tidak semua masyarakat Desa Koto Kandis memilikinya karena dianggap membutuhkan banyak dana untuk membuka lahan mereka menjadi perkebunan kelapa sawit.

\footnotetext{
17 Wawancara dengan Hasanudin, Kepala Desa Koto Kandis Kec. Dendang, tgl 17 Maret 2014.
} 
Pengakuan bapak Ambo, "saya hanya memiliki lahan sedikit sekarang sedang ditanami padi. Jika saya harus merubah lahan saya menjadi perkebunan kelapa sawit jujur saya tidak meiliki biaya. Karena harga bibit sawit unggul sangat mahal, jika hanya ditanami bibit biasa juga sama sekali tidak bagus hasilnya. Terus ditambah harga pupuk juga sangat mahal". ${ }^{18}$

Dari hasil wawancara diatas dengan bapak Ambo"ala" bahwa untuk proses penanaman kelapa sawit itu butuh modal yang besar. Oleh karena itu untuk mencari hasil sampingan demi memenuhi kebutuhan sehari-hari bapak Ambo"ala" mencari atau menambang pasir di Sungai Batanghari yang terdapat di Desa Koto Kandis Kecamatan Dendang. Dengan adanya lokasi penambangan pasir ini sangat berdampak positif bagi masyarakat Desa Koto Kandis karena dengan keterbatasan pendidikan serta rendahnya ekonomi masyarakat mereka masih bisa mencari pasir dengan peralatan seadanya. Bahkan bila harga pasir sedang melonjak naik maka mencari pasir dapat dikatakan sebagai penghasilan yang memuaskan, selain untuk memenuhi kebutuhan hidup sehari-hari. Mereka juga bisa menabung sedikit demi sedikit untuk keperluan sekolah anak mereka.

Pengakuan Bapak Imam " alhamdulilah jika saya menambang pasir itu,pada saat harga sedang mahal maka saya mendapat untung banyak. Kadang-kadang satu pompong bisa mendapat untung 150 ribu. Jadi saya dan istri bisa menabung untuk anak-anak saya kedepannya".45 Penambang ini sendiri walau bukan mata pencarian utama masyarakat Desa Koto Kandis, tetapi setidaknya telah membantu menambah pemasukan bagi masyarakat Desa Koto Kadis. Untuk Desa Koto Kandis tidak mengeluhkan harga pasir hingga saat ini. Sekarang ini harga pasir stabil dan cukup memuaskan. Dampak positif bagi lingkungan sendiri yaitu sejak adanya para penambang pasir maka sungai batanghari yang dulunya dangkal dan banyak kapal yang kandas sehingga saat ini menjadi lebih dalam sehingga perjalanan jalur sungai lebih lancar, banyak juga para nelayan yang mencari ikan disepanjang tempat penambangan ini, jika dulu tidak ada sama sekali pencari ikan yang mencari ikan di sini saat ini mereka mengaku sejak pasir di sungai ini digali oleh penambang jadi banyak ikan yang bersembunyi digalian-galian pasir ini.

Pengakuaan Bapak Hasanuddin "penambang pasir ini sangat berarti bagi kebutuhan kehidupan msyarakat Desa Koto Kandis. Selain itu bagi lingkungan sungai lebih membantu memperlancarkan perjalanan kapal-kapal besar karena karena sebelum ada penambang ini jika air tidak besar maka kapal tidak bisa lewat, jika saat ini semua sudah lancar".19

Dari hasil wawancara diatas dapat kita lihat bersama dengan adanya pertambangan pasir ini ekonomi masyarakat bisa meningkat dan bisa membantu untuk memenuhi kebutuhan ekonomi. Selain berdampak positif penambangan pasir ini juga ternyata berdampak negatif baik bagi warga maupun lingkungan di sekitar Sungai Batanghari. Meskipun pertambangan pasir ini dilakukan dengan tradisional ternyata dapat berdampak negatif terhadap lingkungan mengakibatkan pengelupasan tanah penutup yang menyebabkan kerusakan lapisan tanah bagian atas, lapisan bagian atas ini berfungsi untuk meningkatkan kesuburan tanah, dan

18 Wawancara dengan Ambo" Ala", penambang pasir Desa Koto Kandis Kec. Dendang, tgl 17 Maret 2014.

${ }^{19}$ Wawancara dengan Hasanuddin, Kepala Desa Koto Kandis Kec. Dendang, tgl 17 Maret 2014. 
sistem air bawah tanah, air hujan tidak dapat meresap kedalam tanah secara sempurna sehingga kantong-kantong air di dalam tanah menjadi sedikit, hal ini dapat menyebabkan aliran permukaan menjadi meningkat karena tidak adanya pelindung, apalagi bila pada saat musim hujan. kerusakan pada tanggul Sungai Batanghari dan meningkatnya polusi udara berupa debu di sekitar jalan yang dilalui truk pengangkut pasir sehingga apabila ada truk lewat maka pejalan kaki atau pengguna sepeda motor memilih berhenti agar jauh dari truk serta menutup muka dan hidung untuk menghindari debu yang berterbangan. Berkurangnya kenyamanan masyarakat pengguna jalan karena jalan Desa rusak dan debu beterbangan apabila ada truk lewat, tiap kali diperbaiki maka beberapa waktu kemudian kembali lagi rusak.

Pengakuan Bapak Hasanuddin “ dalam penambangna ini sama sekali tidak ada kontribusinya bagi desa kita, kerusakan jalan juga tidak ada tanggung jawab dari pihak pembeli. Warga juga sebenarnya banyak mengeluh karda polusi udara di sekitar pemukiman warga. ${ }^{20}$ Terpeliharanya ekosistem pada titik keseimbangan yang normal sangat menentukan dalam menciptakan lingkungan yang selaras dan serasi pada kondisi lebih luas lagi, sehingga kemampuan mengkondisikan situasi yang demikian, sangat menunjang dalam menciptakan maupun dilaksanakannya kebijaksanaan terpadu dan menyeluruh dalam memajukan kesejahteraan umum. ${ }^{21}$

Dari uraian diatas dapat diambil suatu kesimpulan bahwa dengan adanya penambangan pasir seperti ini akan mendatangkan bencana bagi kehidupan manusia seperti kotor dan keruhnya air Sungai Batang hari akibat tergerus aliran Sungai Batanghari, dan udara makin kotor menyebabkan penyakit. Dengan demikian maka masyarakat akan terkena akibatnya, terlihat jelas bahwa dampak negatif dari pertambangan pasir itu sangat merugikan bagi masyarakat, semoga pihak yang melakukan pertambangan pasir bisa sadar apa yang telah mereka lakukan.

\section{Pandangan Hukum Islam terhadap Komersialisai Penambangan Pasir}

Dalam pandangan Islam, sumber daya alam (SDA) pada hakikatnya milik absolut Allah SWT yang diamanatkan pengelolaan, pemanfaatannya dan pelestariannya kepada manusia. Sumber daya alam (SDA) yang termasuk milik umum seperti air, api, padang rumput, hutan, dan barang tambang harus dikelola hanya oleh Negara yang hasilnya harus dikembalikan kepada rakyat dalam bentuk pelayanan dalam memenuhi kebutuhan dasar seperti sandang, pangan, papan, pendidikan, kesehatan, dan fasilitas umum. Dalam pengelolaan, eksplorasi dan eksploitasi sumber daya alam (SDA) harus memperhatikan kelestarian alam dan lingkungan serta keberlanjutan pembangunan. Pengelolaan sumber daya alam (SDA), baik yang dapat diperbaharui maupun yang tidak dapat diperbaharui, harus memperhatikan daya dukun dan daya tampung lingkungan hidup dan sosial budaya masyarakat, untuk mencapai efesiensi secara ekonomis dan ekologis dengan menerapkan teknologi dan cara yang ramah lingkungan. Penegakan hukum merupakan suatu keniscayaan dalam pengelolaan sumber daya alam (SDA) untuk

${ }^{20}$ Wawancara dengan Hasanuddin, Kepala Desa Koto Kandis Kec. Dendang, tgl 17 Maret 2014.

${ }^{21}$ P. Joko Subagyo, Hukum Lingkungan, ( Jakarta :Rineka Cipta, 1992), hlm. 2. 
menghindari perusakan sumber daya alam (SDA) dan pencemaran lingkungan. ${ }^{22}$ Dalam proses komersialisasi penambangan pasir yang terjadi di Desa Koto Kandis dapat ditinjau dari berbagai segi yang termasuk dalam hukum Islam diantaranya:

A. Ditinjau dari Al-Qur'an

Di lingkungan kita terdapat sumber kekayaan yang berada di dalam perut bumi dikenal sebagai bahan tambang. Bahan-bahan tambang itu sangat bermanfaat bagi kehidupan manusia. Apabila kita telaah sejumlah ayat Al-Qur"an, disana kita dapati isyarat tentang adanya mineral dalam bumi yang dapat dikeluarkan melalui eksplorasi pertambangan. ${ }^{23}$ Dalam Al-Qur'an menjelaskan yang artinya:

"Dialah yang menciptakan langit dan bumi dalam enam masa: Kemudian dia bersemayam di atas 'arsy. dia mengetahui apa yang masuk ke dalam bumi dan apa yang keluar daripadanya dan apa yang turun dari langit dan apa yang naik kepadaNya dan dia bersama kamu di mama saja kamu berada. dan Allah Maha melihat apa yang kamu kerjakan".24

Ayat tersebut memberikan gambaran dan isyarat yang merangsang manusia untuk melakukan eksplorasi kekayaan alam. Bahwa apa yang masuk dalam bumi dan keluar dari padanya memberikan petunjuk adanya suatu yang tersimpan dalam perut bumi yang perlu diteliti. Selain ayat diatas ada juga ayat yang menjelsakan yang artinya:

"Dan carilah pada apa yang Telah dianugerahkan Allah kepadamu (kebahagiaan) negeri akhirat, dan janganlah kamu melupakan bahagianmu dari (kenikmatan) duniawi dan berbuat baiklah (kepada orang lain) sebagaimana Allah Telah berbuat baik, kepadamu, dan janganlah kamu berbuat kerusakan di (muka) bumi. Sesungguhnya Allah tidak menyukai orang-orang yang berbuat kerusakan". ${ }^{25}$

Analisis hukum Islam terhadap penambangan menunjukkan bahwa Islam melarang kegiatan penambangan yang merusak terhadap lingkungan, dan diwajibkan untuk menjaga dan memelihara kelestarian lingkungan agar tidak terjadi hal-hal yang merugikan manusia akibat penambangan pasir dialiran sungai batanghari. Sebagaimana firman Allah SWT yang artinya:

"Telah nampak kerusakan di darat dan di laut disebabkan karena perbuatan tangan manusia, supaya Allah merasakan kepada mereka sebahagian dari (akibat) perbuatan mereka, agar mereka kembali ke jalan yang benar". 26

Serta al-baqarah yang artinya: "Dia-lah Allah, yang menjadikan segala yang ada di bumi untuk kamu dan dia berkehendak (menciptakan) langit, lalu dijadikan-Nya tujuh langit. dan dia Maha mengetahui segala sesuatu". ${ }^{27}$

${ }^{22}$ K.H. Ma"ruf, dkk., Himpunan Fatwa majelis Ulama Indonesia, (Jakarta : Erlangga, 2010), hlm.853.

23 Kaelany, Islam dan Aspek-aspek Kemasyarakatan, (Jakarta: Bumi Aksara, 2005), hlm.203

24 QS. Al-Hadid. ( 57) : 4

25 QS. Al- Qashash (28) : 77

${ }^{26}$ QS. Ar-Rum (30) : 4154 QS. Al-baqarah (02) : 29

27 QS. Al-baqarah (02) : 29 
Manusia sebagai ciptaan Allah, salah satu kewajiban atau tugasnya adalah membuat bumi makmur. Ini menunjukkan bahwa kelestarian dan kerusakan alam berada di tangan manusia, manusia harus mengiringi alam, antara lain memelihara kelestarian alam dan mengarahkannya kearah yang lebih baik dan bukannya melakukan perusakan di muka bumi. Sekali lagi, Islam membolehkan Pengelolaan bumi dan pemanfaatannya dengan syarat kelestarian dan keberlangsungannya, jangan sampai merusak habitat alam.

Berdzikir dengan selalu ingat kepadanya juga selalu mengingat ciptaannya dan tujuan dari ciptaannya itu. Sedangkan bersyukur kepada Allah dengan berterima kasih atas nikmat dan karunianya juga memanfaatkan nikmat dan karunia itu untuk kemaslahatan sesuai dengan tujuan penciptaan dan tuntunannya. Bagi kita umat Islam, usaha pelestarian lingkungan bukan hanya semata-mata karena tuntutan ekonomis atau politis atau karena desakan program pembangunan nasional. Usaha pelestarian lingkungan harus dipahami sebagai perintah agama yang wajib dilaksanakan oleh manusia bersama-sama. Setiap usaha pengelolaan dan pelestarian lingkungan hidup secara baik dan benar adalah ibadah kepada Allah SWT yang dapat memperoleh karunia pahala. Sebaliknya, setiap tindakan yang mengakibatkan kerusakan lingkungan hidup, pemborosan sumber daya alam, dan menelantarkan alam ciptaan Allah adalah perbuatan yang dimurkainya. Karena itu tergolong sebagai perbuatan maksiat atau munkar yang diancam dengan siksa. Menurut Islam Al-Quran alam bukan hanya benda yang tidak berarti apa-apa selain dimanfaatkan untuk memenuhi kebutuhan manusia. Alam dalam pandangan Islam Al-Quran adalah tanda (ayat) "keberadaan" Allah. Alam memberikan jalan bagi manusia untuk mengetahui keberadaannya. Allah berfirman yang artinya:

"Dan di bumi itu terdapat tanda-tanda (kekuasaan Allah) bagi orang-orang yang yakin".28

Dalam Al-Quran banyak ditemukan ketika berbicara tentang alam dilanjutkan dengan anjuran untuk berfikir memahami, mengingat, bersyukur, dan bertafakkur. Semua ini akan mengantarkan manusia kepada sesuatu yang Maha Mutlak yang menciptakan alam dengan keharmonisan hukum-hukum yang mengaturnya. Alam adalah tanda-tanda (ayat) Allah, dalam artian bahwa alam mengabarkan akan keberadaan Allah sebagai pencipta alam.

Selain dalam Al-Quran Rasulullah SAW juga melarang manusia untuk tidak menjual belikan hasil kekayaan alam yaitu berupa air, padang rumput,dan api sebagaimana sabada Nabi SAW yang artinya:

"Kaum muslimin berserikat dalam tiga hal : air, padang rumput gembalaan, dan api. Harga (menjual-belikanya) adalah haram" (HR. Ibnu majah dan Abu Dawud)

Menurut Ibnu Khaldun dalam muqaddimah, manusia harus memanfaatkan kekayaan alam untuk kemaslahatan manusia dengan tetap menjaga kelestarian. Abu Yusuf dan Abu Ya"la menegaskan agar tidak membiarkan kekayaan alam tidak termanfaatkan. Abu yusuf mengatakan, kepala negara tidak boleh membiarkan tanah yang tidak bertuan tanpa pengelolaan dan kepela Negara dapat menyerahkan hak pengelolaan tanah tersebut kepada masyarakat. ${ }^{29}$

${ }^{28}$ QS. Adz-Dzariyat (51) :20. hlm.855

${ }^{29}$ K.H. Ma"ruf, dkk., Himpunan Fatwa majelis Ulama Indonesia, (Jakarta : Erlangga, 2010), 
Fatwa Majelis Ulama Indonesia (MUI) bersama Kementerian Lingkungan Hidup dalam upaya merubah perilaku dan meningkatkan kesadaran Umat Muslim sebagai potensi terbesar bangsa, atas pentingnya perlindungan dan pengelolaan lingkungan hidup dalam pemanfaatan sumber daya alam (khusus pertambangan) harus sesuai dengan Kaidah Syariah.

MUI telah menandatangani Memorandum Of Understanding (MOU) No. 14/MENLH/12/2010 dan Kep-621/MUI/XII/2010 pada tanggal 15 Desember 2010, telah disepakati bersama Fatwa Majelis Ulama Indonesia No. 22 Tahun 2011 tentang Pertambangan Ramah Lingkungan. Fatwa MUI ini merupakan bentuk pendekatan moral dalam pelaksanaan perlindungan dan pengelolaan lingkungan hidup.

Sekarang ini, sudah sepatutnya Islam bisa menjadi solusi bagi segala permasalahan di dunia ini, termasuk pertambangan. Pertambangan Indonesia yang kini kurang menguntungkan dari segi kesejahteraan masyarakat dan kurang bersahabat dengan lingkungan sudah sepatutnya berubah. Indonesia dengan kekayaan alam tambangnya harus mandiri, rakyatnya sejahtera secara ekonomi. Begitu pula dengan pengelolaannya, Indonesia harus mempertegas batas kerusakan lingkungan yang ditimbulkan dari aktivitas penambangan. Bahkan sudah sepatutnya perusahaan mengembalikan rona lingkungan yang awalnya hijau dan indah. Pemerintah harus tegas, harus berani menindak perusahaan nakal yang tidak memperhatikan aspek lingkungan dalam proses penambangannya. Islam dengan jelas mengatur hal itu. Jadi, majulah pertambangan demi pembangunan. ${ }^{30}$

Ahli hukum Ibn Al-Quayyim Berkata mengenai kerusakan itu: "Bila orang merenungkan hukum yang telah ditetapkan oleh yang Maha Kuasa bagi ciptaanya, ia akan mengetahui bahwa semua itu direncang untuk menjamin adanya keseimbangan manfaat dan bila terjadi perselisihan, hal yang lebih penting harus diutamakan dari pada hal yang kurang penting, adanya hukum untuk mencegah tindakan yang merugikan, namun bila kerugian tidak terelakkan maka yang dipilih adalah yang lebih ringan mudharatnya, inilah prinsip yang terkandung dalam hukum Tuhan, dengan penuh perasaan berbicara tentang kebijaksanaan dan belas kasihnya" dasar ketentuan ini adalah ucapan Nabi SAW: "tindakan yang merugikan tidak diperbolehkan, baik itu yang menguntungkan sipelaku maupun tidak"31

Kesempurnaan ciptaan yang telah Allah berikan kepada manusia seharusnya mendorong manusia untuk mempertimbangkan akal fikir dan hati nuraninya dalam mengelola dan melestarikan alam dan lingkungannya. Pertimbangan akal fikir dan hati nurani selanjutnya dibimbing oleh sikap tunduk dan pasrah pada Allah SWT sebagai Dzat yang Mencipta dan Menguasai alam, sehingga akan melahirkanm perilaku yang baik dan bertanggungjawab. Apabila setiap manusia memiliki kesadaran semacam ini, maka setiap manusia akan melahirkan perilaku yang baik terhadap lingkungannya, sehingga akhirnya akan terciptanya budaya masyarakat yang peduli dan ramah lingkungan.

Budaya peduli dan ramah lingkungan yang merupakan manifestasi Akhlaq lingkungan yang tercipta dalam kehidupan masyarakat tidak hanya akan berdampak pada terciptanya kesetimbangan hidup manusia, alam dan

${ }^{30}$ Fatwa Majelis Ulama Indonesia (MUI) No. 22 Tahun 2011 tentang Pertambangan Ramah Lingkungan, 5 Juni 2011.

31 Mifta al-Saadah, (1992), hlm. 350 
lingkungannya, tetapi berdampak pula bagi penciptaan kehidupan masyarakat yang beradab dan berbudaya. Sikap inilah yang selanjutnya akan mengantarkan kehidupan masyarakat yang lebih baik di masa kini dan masa depan. Bumi pun akhirnya menjadi lebih sejuk, nyaman bagi hidup dan kehidupan, dan menjamin kelangsungan hidup generasi yang akan datang. ${ }^{32}$

B. Kaidah Khusus Bidang Muamalah atau Transaksi.

Berdasarkan Hukum Fiqh Muamalah yang artinya: "Hukum asal dalam semua bentuk Muamalah adalah boleh dilakukan kecuali ada dalil yang melarangnya. ${ }^{33}$ Maksud kaidah in adalah bahwa dalam setiap Muamalah dan transaksi, pada dasarnya boleh, seperti jual beli, sewa menyewa, gadai, kerja sama, perwakilan, dan lain-lain, kecuali yang tegas-tegas diharamkan sepeti mengakibatkan kemudaratan, tipuan, judi, dan riba. Fiqh Muamalah pada awalnya mencakup semua aspek permasalahan yang melibatkan interaksi manusia, seperti pendapat Wahbah Zuhaili, hukum muamalah itu terdiri dari hukum keluarga, hukum kebendaan, hukum acara, perundang-undangan, hukum internasional, hukum ekonomi dan keuangan. Tapi, sekarang Fiqh Muamalat dikenal secara khusus atau lebih sempit mengerucut hanya pada hukum yang terkait dengan harta benda.

Begitu pentingnya mengetahui Fiqh ini karena setiap muslim tidak pernah terlepas dari kegiatan kebendaan yang terkait dengan pemenuhan kebutuhannya. Maka dikenallah objek yang dikaji dalam fiqh muamalat, walau para fuqaha (ahli fiqih) klasik maupun kontemporer berbeda-beda, namun secara umum fiqh muamalah membahas hal berikut : teori hak-kewajiban, konsep harta, konsep kepemilikan, teori akad, bentuk-bentuk akad yang terdiri dari jual-beli, sewamenyewa, sayembara, akad kerjasama perdagangan, kerjasama bidang pertanian, pemberian, titipan, pinjam-meminjam, perwakilan, hutang-piutang, garansi, pengalihan hutang-piutang, jaminan, perdamaian, akad-akad yang terkait dengan kepemilikan: menggarap tanah tak bertuan, ghasab (meminjam barang tanpa izin), merusak, barang temuan, dan syuf"ah (memindahkan hak kepada rekan sekongsi dengan mendapat ganti yang jelas). Tujuan hukum Islam adalah aturan yang dijalankan untuk mencapai kebahagiaan hidup manusia di dunia ini dan di akhirat dengan mengambil segala manfaat dan mencegah mudarat atau keburukan yang tidak berguna bagi kehidupan.

\section{Lima Kaidah Asas}

Lima kaidah dibawah ini sangat masyhur dikalangan mazhab Al-Syafi"i khususnya dan di kalangan mazhab-mashab lain umumnya, meskipun urutannya tidak selalu sama. Dalam tulisan ini, kelima kaidah tersebut akan dijelaskan dengan urutan:

1) Setiap perkara tergantung pada niatnya

2) Keyakinan tidak bisa dihilangkan karena adanya keraguan

3) Kesulitan mendatangkan kemudahan

4) Kemudharatan ( harus ) dihilangkan

5) Adat (dipertimbangkan didalam ) menetapkan hukum

32 Tajrih Muhammadiyah, Akhlaq Lingkungan Panduan Berperilaku Ramah Lingkungan, (Yogyakarta: Deputi Komunikasi Lingkungan dan Pemberdayaan Masyarakat Kementerian Lingkungan Hidup dan Majelis Lingkungan Hidup Pimpinan Pusat Muhammadiyah, 2011), hlm. 46.

${ }^{33}$ Himpunan Fatwa Dewan Syariah Nasional ( DSN ) Kerja Sama MUI dengan Bank Indonesia, Edisi Kedua Tahun 2003. 
Dalam proses kegiatan penambangan di Desa Koto Kandis termasuk kedalam kaidah asasi yang ke-empat yang artinya: "Kemudharatan (harus) dihilangkan". Karena dalam proses komersialisasi penambangan yang dilakukan oleh masyarakat Desa Koto Kandis sangat berdampat tidak baik bagi masyarakat sekitar. Selain itu hasil dari komersialisasi hasil tambang tidak ada masuk dalam pendapatan Desa atau kas Desa. Sehingga untuk Desa sendiri tidak dapat membangun jalan-jalan yang rusak akibat truk-truk yang mengangkut pasir tersebut. Seperti dikatakan oleh Izzuddin ibn Abd Al-Salam bahwa tujuan Syariah itu adalah unutk meraih kemaslahatan dan menolak memafsadatan. Apabila diturunkan kepada tataran yang lebih konkret maka maslahat membawa manfaat sedangkan mafsadah mengakibatkan kemudharatan. Dalam kehidupan ini, sering dihadapkan kepada pilihan-pilahan yang tidak mudah. Pilihan-pilihan itu dihadapkan kepada kita, baik dalam masalah-masalah yang bersifat individual, kehidupan keluarga, maupun masyarakat, sering juga dihadapkan oleh para pemimpin Negara bahkan pemimpin dunia.

Sebaliknya ketetapan dalam menentukan pilihan akan membawa kemanfaatan, kalau tidak pada waktunya sekarang, manfaatnya akan tiba pada masa yang akan datang. ${ }^{34}$ Karena manusia itu terikat oleh ruang dan waktu, maka pilihannya pun terikat oleh ruang dan waktu. Dalam hal ini pilihan-pilihan tersebut mengedepankan skala prioritas, mana yang harus didahulukan dan mana yang diakhirkan, mana yang lebih penting dan mana yang kurang penting, mana yang mendesak dan mana yang tidak begitu mendesak, mana yang menyangkut pribadi atau keluarga dan mana yang menyangkut orang banyak.

Makin besar ruang lingkup masalah yang dihadapi, maka makin besar pula tuntutan kearifan dalam menentukan pilihan dan makin besar resiko yang dihadapinya apabila salah dalam menentukan pilihannya, serta makin besar manfaat yang diraih apabila tepat dalam pilihannya. Kemampuan memilih secara tepat juga berarti mampu menempatkan sesuatu pada tempatnya. Inilah ciri keadilan menurut para Ulama. Imam Izzuddin zbin Abd al-Salam mengungkapkan yang artinya: "menolak kemudharatan lebih utama dari pada meraih manfaat". Kaidah ini menegaskan bahwa apabila pada waktu yang sama dihadapkan kepada pilihan menolak kemafsadatan atau meraih kemaslahata, maka yang harus didahulukan adalah menolak kemafsadatan.

Karena dengan menolak kemafsadatan berarti meraih kemaslahatan. Sedangkan tujuan hukum Islam ujungnya adalah untuk meraih kemaslahatan didunia dan akhirat. Kemaslahatan membawa manfaat bagi kehidupan bagi manusia, sedangkan mafsadah mengakibatkan kemudaratan bagi kehidupan manusia ${ }^{35}$ yang artinya: "kemaslahatan yang umum lebih didahulukan dari pada kemaslahatan yang khusus". Kaidah diatas menegaskan bahwa apabila berbenturan antara kemaslahatan umum dengan kemaslahatan yang khusus, maka kemaslahatan yang bersifat umum yang harus didahulukan, karena dalam kemaslahatan yang umum itu terkandung pula kemaslahatan yang khusus, tetapi tidak sebaliknya. Dalam proses komersialisai diatas jelas lebih mementingkan kemaslahatan khusus atau kepentingan pribadi. Pertama tidak adanya sumbangsih

${ }^{34}$ A. Djazuli, Kaidah-kaidah fikih, ( Jakarta : Kencana, 2011), hlm. 163

35 Ibid., hlm. 164-165 
ke Desa sebagai sumbangan untuk pembangunan dalam berbagai hal. Kedua tidak adanya izin penambangan yang sah walau penambangan ini dilakukan dengan cara tradisional dan masih banyak lagi yang lainya.

Dalam kelima hal yang menjadi batasan secara umum bahwa transaksi yang dilakukan sah atau tidak maka dalam proses komersialisasi yang dilakukan oleh masyarakat termsuk dalam ketegori haram bagi para penggali pasir. Karana dari proses inilah yang mengakibatkan lingkungan tercemar. Namun tidak bagi para pembeli hasil tambang tersebut, karena para pembeli tidak mengetahui secara pasti bagaimana pasir tersebut didapat yang mereka tahu pasir tersebut sudah tersedia dipenampungan sehingga mereka beli dan tinggal angkut saja. Ulama menyebutkan keharaman yang menuju kepada mafsadah dengan haram li ghayrihi. Sedangkan keharaaman yang mafsadahnya berdiri sendiri disebut haram li dzatihi. Sehingga muncul kaidah lain yang artinya: "apa yang diharamkan karena sadd aldzari'ah, dibolehkan dilakukan apabila ada kemaslahatan yang lebih kuat".

\section{Penutup}

Setelah memahami beberapa tinjauan hukum Islam diatas tentang kegiatan komersialisasi penambangan maka dapat disimpulkan bahwa setiap proses pengelolaan sumber daya alam (SDA) maka manusia tidak boleh sampai melampaui batas. Setiap bagian dari Sumber daya alam yang ada dimuka bumi ini tidak dapat bertahan lama. Seperti halnya pasir yang ada dialiran sungai batang hari lama-lama akan terkikis dan habis, maka berakibat buruk baik bagi lingkungan itu sendiri maupun manusia yang ada di sekitanya. Ayat - ayat diatas adalah ayat yang menjadi landasan teologis pembenaran Pengelolaan dan pemanfaatan sumber daya alam untuk memenuhi kebutuhan manusia. Islam tidak melarang memanfaatkan alam, namun ada aturan mainnya. Manfaatkan alam dengan cara yang baik (bijak) dan manusia bertanggungjawab dalam melindungi alam dan lingkungannya serta larangan merusaknya.[]

\section{BIBLIOGRAFI}

Anonim. Himpunan Fatwa Dewan Syariah Nasional (DSN), Kerja Sama MUI dengan Bank Indonesia, Edisi Kedua, Tahun 2003.

A. Djazuli, Kaidah-kaidah fikih, Jakarta: Kencana, 2011.

Departemen Agama RI. Al-Quran dan Terjemahannya.

Dessy Anwar, Kamus Besar Bahasa Indonesia, Surabaya: Amelia Surabaya, 2005.

Fatwa Majelis Ulama Indonesia (MUI) No. 22 Tahun 2011 tentang Pertambangan Ramah Lingkungan, 5 Juni 2011.

Hamzah Ya'qub, Etos Kerja Islami, Jakarta: Pedoman Ilmu Jaya, 1992.

Jaelany, Islam dan Aspek-aspek Kemasyarakatan, Jakarta: Bumi Aksara, 2005.

Lembaga Tarjih Muhammadiyah, Akhlaq Lingkungan Panduan Berperilaku Ramah

Lingkungan, Yogyakarta: Deputi Komunikasi Lingkungan dan

Pemberdayaan Masyarakat Kementerian Lingkungan Hidup dan Majelis

Lingkungan Hidup Pimpinan Pusat Muhammadiyah, 2011. 
Ma'ruf, dkk., Himpunan Fatwa majelis Ulama Indonesia, Jakarta: Erlangga, 2010.

M. Luthfi Hamidi, Jejak-jejak Ekonomi Syariah, Jakarta: Senayan Abadi, 2003.

Pemerintah Desa Koto Kandis, Ekonomi desa Koto Kandis, Maret 2014.

P. Joko Subagyo, Hukum Lingkungan, Jakarta: Rineka Cipta, 1992.

Totok Suhartono, "Pertambangan Bahan Galian Golongan C" http://data. menkokesra. go.id/ content/ program- penyehatan-lingkungan akses 22 Januari 2014. 